\title{
Concept of a Sustainable Economy of a Trade Enterprise
}

\author{
Nadezhda Necheukhina, and Olga Mustafina \\ Ural State University of Economics, 8 Marta Str., 62, 620144 Yekaterinburg, Russia
}

\begin{abstract}
The article presents the results of scientific research on the problem of system monitoring of sustainable development of the microlevel economic system. The authors prove that the stability of economic systems is characterized by the ability to return to equilibrium under the influence of external and internal factors. Currently, the problem of ensuring sustainable economic development is debatable and actively discussed. This circumstance determined the relevance of the chosen scientific direction of research, the purpose of which was to develop a scientifically based conceptual position of the economic and financial stability of the trade enterprise. The goal of the study was achieved by applying the constructive direction of system research (system analysis) in the framework of systems theory and decision-making. The scientific and practical significance of the presented results lies in the development of the authors ' conceptual position that provides an understanding of the problems of economic stability and the need for systematic, timely diagnosis, and subsequent management decision-making to reduce the risks of loss of stability of the economic system.
\end{abstract}

\section{Introduction}

The formation of economic views should not be a compilation and translation of popular textbook representations of economic teachings. This circumstance prompted the authors to change the classical approach and develop their own point of view on the economic processes taking place in the modern economic space, based on the field of scientific knowledge. Sustainability is an important characteristic and direction of scientific research. The concept of "stability" is the main and qualitative property of modern management theory. Taking into account the peculiarities of economic systems, sustainability should be considered as a reflection of the binary nature of natural development processes and manageability. The theoretical foundations of system stability are the object of study of various areas of scientific knowledge: employment theory,economic cycle theory, economic growth theory, economic and mathematical modeling, reliability theory, etc. The sustainability of economic systems differs significantly from physical or technical sustainability. As a rule, the loss of stability of the economic system is observed during the transition from one state to another, and can be accompanied by crisis manifestations. 


\section{Materials and methods}

\subsection{Discussion on economic sustainability}

In the general sense, "stability" is the ability of a system to maintain its current state under the influence of exogenous influences [1]. In the dictionary of Ozhegov S. I., stability is not subject to fluctuations; constant and persistent [2]. Sustainability in the broadest sense, a system's ability to function in a state sufficiently close to equilibrium in terms of external and internal changes [3]; and in the narrow sense of the word - sustainability of the enterprise (economic system). If there are synonyms that are similar in essence, "stability" is reliability, that is, the ability of a phenomenon (process, system, etc.) maintain its essence when changing internal and external conditions. Any economic system is in constant motion and development, which in turn is characterized by the stability of the dynamic system, and its ability to return to an equilibrium state after the end of the action that violated this equilibrium [4,5]. Thus, sustainability is a rather versatile concept that is reflected in various fields of scientific knowledge. At the present stage of development of the Russian economy, issues related to the stability of economic systems are of particular relevance, and the authors limit the field of scientific knowledge within the boundaries of the stability of the enterprise economy. L. I. Abalkin [6], A. L. Bobrov and K. V. Papenkov [7], D. V. Gordienko [8] and others. identify the stability of the enterprise economy with the criteria of stability, security, and reliability of operation.I. N. Petrenko [9], characterizes the stability of the enterprise economy as the ability to preserve the functional parameters of changes in external and internal business conditions. Scientific discussions about the essence of the sustainability of the enterprise economy among scientists and practitioners are growing, due to the lack of a common conceptual position. Accordingly, the semantic boundaries of the concept, content and criteria for assessing the "sustainability of the enterprise economy" are in the center of scientific attention. The scientific community often talks about "financial stability" and "economic stability", so the author's arguments are aimed at forming a scientifically based position on the use of these concepts. Moreover, you should pay attention to the presence of many definitions in relation to the objects of author's reasoning. Thus, financial stability is considered as: a goal-setting property of opportunities, means and ways to strengthen the economy [10]; the ability to function and develop, maintaining the balance of its assets and liabilities in the changing conditions of the external and internal environment [11]; characterized by the ratio of own and borrowed funds [12]; the state in which the company has sufficient capital to ensure the continuity of its activities [13]; a stable position with the constant availability of the necessary amounts of funds in Bank accounts, and the absence of overdue debt [14]; the state of the company's accounts, guaranteeing solvency $[15,16]$;independence from the randomness of the market environment and the behavior of partners [17]; a generally accepted key characteristic of the financial condition [18]. In turn, the economic stability of an enterprise is a rational and efficient use of its financial resources [19]; a set of properties of organizational, innovative, logistics, production, financial and credit activities, taking into account mutual influence and interaction [20]; innovative potential of sustainable development and its effective use to neutralize external influences and destabilization factors [21]; the state in which socioeconomic parameters maintain their initial equilibrium and are within the specified limits under the influence of the internal and external environment [22]; the ability to maintain the current state of functioning, adapt to changes in the internal and external environment, the ability to maintain activity and development [23].

Research of various points of view allows the authors to conclude that there is no unambiguous position in relation to the studied aspects. Speaking about the financial and economic stability of the enterprise, as the main criteria that characterize the economy of 
the micro-level system, we can distinguish the following: 1) economic stability, characterized as a set of different properties of socio-economic development of the economy; 2) financial stability, this is the main parameter or property that is an indicator of economic stability. Therefore, the concept of "economic stability" is broader than "financial stability". Thus, the economic stability of an enterprise is a complex socio-economic characteristic that allows you to assess the competitiveness or rating of an enterprise in a territorial or industrial market, using a system of criteria for a comprehensive economic assessment. In turn, financial stability is a property that characterizes the financial structure of an enterprise, and is a complex parameter for assessing the economic stability of a micro-level system.

Criteria for the stability of the economy of a trade enterprise

The activity of trade enterprises can be characterized as the result of transformation processes, socio-economic development of territories, and therefore special attention is paid to the assessment (monitoring) of economic and financial stability [24, 25]. In the literature, you can find a sufficient number of methodological positions regarding the monitoring (analysis) of the studied aspect. Traditionally, the assessment of the economic and financial stability of a trade enterprise is carried out using a system of local indicators that respond to various aspects of financial risk. These factors include: 1) macroeconomic factors of indirect influence (taxation, income and propensity to consume and save households in the territory, inflation rates, forms and methods of financial regulation, etc.); 2) macroeconomic factors of direct influence (the practice of providing commercial credit, the level of stability of commercial relations, the level of transparency of the financial market, etc.); 3) microeconomic factors - the internal financial environment of the trade enterprise (income, expenses, break-even operations, profit, financial risk, etc.). in the foreign practice of system monitoring, the stability of the enterprise's economy is assessed using a system of complex integral indicators that characterize the economic potential of the system [26, 27]. The most popular integral indicator for assessing economic and financial stability is the Zmodel,developed by the American economist, Professor of Finance at New York University E. I. Altman (formula 1 and 2).

$$
Z=-0,3877-1,0736 * X 1+0,579 * X 2(1)
$$

Where X1 - current liquidity ratio, which is calculated as a multiple of the ratio of current assets and current liabilities; $\mathrm{x} 2$ - the index structure of borrowed capital in the total cost of sources of formation of property of the enterprise.

$$
\mathrm{Z}=1.2 * \mathrm{X} 1+1.4 * \mathrm{X} 2+3.3 * \mathrm{X} 3+0.6 * \mathrm{X} 4+\mathrm{X} 5(2)
$$

The results of calculations can be characterized by different variants of the level of economic and financial stability of the enterprise. Option 1 if the calculated indicator is $\leq$ 1.8 , which indicates a high risk of insolvency $(80 \%-100 \%)$. Option 2 in the range from 1.81 to 2.7 indicates an average risk of insolvency ( $35 \%$ to $50 \%$ ). Option 3 (estimated value from 2.8 to 2.9 ) indicates normal economic and financial stability, with a low probability of insolvency $(15 \%$ to $20 \%$ ). Option 4 , provided $\geq 3.0$, which indicates a fairly high level of stability of the enterprise's economy. Thus, the integral indicator of economic and financial stability allows you to comprehensively assess the stability of the enterprise's economy. You should note that the components of Z-models are generated on the basis of accounting and analytical data of the accounting (financial) statements, which allows to generate a matrix of criteria of the sustainable economy: criteria (X1) is a measure of the structure of working capital to total asset of the enterprise; criterion (x2), an indicator of the structure of the undistributed profits to the total sum of sources of formation of property; criterion (X3), the ratio of operational profits, which is defined as the difference between amounts of income (revenue) and expenditure (expenses on purchase of goods and implementation) to the total assets criterion (X4) - defined as the ratio of market value to net asset value.

Methodology for analyzing the economic and financial stability of an enterprise 
In general, economic and financial stability is achieved due to the ability to maintain a quality state, both in the territorial economic space, and the ability of the enterprise to ensure financial balance of the balance of the capital structure. This is possible due to the controllability of the parameters of the impact on the economic system [28]. It is obvious that stability and manageability, these are antagonistic categories and achieving a balance of equilibrium, is an end in itself of any economic system. Given the uncertainty of economic development and the impact of factors on economic and financial stability (as the authors mentioned earlier in paragraph 1.2), we can talk about various options for a stable and unstable state of the economic system. A highly stable economic system, characterized by the ability to fulfill its obligations in a timely manner, as well as the ability to reproduce in incremented (increased) volumes. In turn, a low-stable economic system is not able to meet obligations for various aspects of financial and economic activities, while development and reproduction are usually accompanied by stagnation of volumes. And here we are not talking about extended reproduction, we are talking about maintaining simple reproduction or achieving break-even(threshold value). The state of break-even is characterized by the condition of balance of income and expenses, which makes it possible to neutralize the negative (negative) impact on economic and financial stability. The stock of financial stability can be used as the main indicator that provides opportunities for economic and financial stability [29]. Excess of losses over the margin of financial stability means that the economic system cannot reach the break-even state (threshold value). To assess the stability of the economic system, you can use a set of time indicators: asset turnover, cash turnover rate, etc. [30]. However, system recovery depends on the speed of the enterprise resource activation process. According to various estimates, the duration of recovery of economic stability varies from 6 to 8 years, and financial stability from 3 to 5 years. It is obvious that the possibility of returning to the state of economic equilibrium depends on the availability of resources that require compensatory losses and the timely possibility of activating the turnover rate, the resources of the enterprise. Otherwise, the loss of economic and financial stability leads to irreversible consequences [31].

Thus, timeliness of analysis, criteria and parameters of a desired state of sustainability, allows to accumulate financial management the aspect of manageability sustainability of the economy. Therefore, it is appropriate to talk about a quantitative assessment of the stock of financial stability and the period for achieving the desired state. An important feature of the financial stability of an enterprise is the quality of the aggregate of all assets (A) ranked by the degree of liquidity, and the quality of the aggregate of liabilities (P) ranked by the maturity of obligations. Comparison of ranked groups of assets and liabilities gives an overall picture of financial stability and the ability to meet their obligations. Thus, any micro-level economic system is characterized by the availability of resources and their sources of education. The stability of the system is determined by the result of ranking and comparing the above criteria. It is obvious that the availability of reserves, when compared, makes it possible to reduce the time to achieve a stable state, and stabilize economic and financial stability.

\section{Results of the discussion}

Sustainable economic and financial development of the micro-level economic system requires local sustainability [32]. The purpose of any system of this level is to generate income that allows you to cover the invested (spent) resources and influence the structure of the property and its sources of formation, in the amount of net profit, which is added to the company's own funds and has a positive impact. 


\subsection{The concept of a sustainable enterprise economy}

Traditionally, the stability of the enterprise economy is characterized by net profit, which affects the forecasting and decision-making process. Profit is a means of evaluating the results of activities that affect the value of assets and the well - being of business owners. Therefore, there is a need to maximize profits.In accounting theory, profit is given sufficient importance, which is confirmed by the presence of conceptual positions: 1) the syntactic approach provides a critical review of the rules for determining profit; 2) the semantic approach highlights the relationship between profit and the underlying reality; 3 ) the pragmatic approach takes into account the interests of owners and investors. Thus, profit is a criterion for the capabilities of a trading enterprise, and the authors believe that profit is a significant criterion for the stability of the enterprise's economy. Profit is the result of the ratio of income and expenses. It should be emphasized that in the practice of economic activity there may be different types of income and expenses. Then the profit is an integrated indicator that characterizes the results of comparing different types of income and expenses. Moreover, the enterprise's profit of trade depends on regular events, results, which are characterized by the income from the sale of goods and related services; from sales to non-trading activities; from the sale of other property; from non-operating transactions [33]. At the same time, recurring events cause regular expenses that are reasonably divided (compared) in relation to types of income.

The author's conceptual position of a sustainable enterprise economy is focused on possible recipients of economic benefits. Therefore, the sustainability of the enterprise's economy can be assessed using priority indicators: 1) Value added, which is determined by the dependence of the sales price minus the cost of goods and services purchased on the side. 2) Net profit of the enterprise, as the ratio of excess of income over expenses. 3) Net profit of investors is the net profit after taxes. 4) Net profit of shareholders, the result of the difference between the net profit of investors and interest payments. 5) Net profit of holders of ordinary shares is the net profit of shareholders after payment of dividends on preferred shares.

\section{Conclusions}

The stability of the economy of a trade enterprise is a rather complex and comprehensive property that determines the possibility of functioning in the territorial industry market. Profit is the main indicator of efficiency and the main factor of priority indicators of economic benefits for various recipients. The presented conceptual views are focused on the current goals of business and stakeholders. If we take into account the socioeconomic significance of profit, it should be reflected in the report as earned, which is subject to subsequent distribution. Note that the concept of sustainability of the enterprise economy requires recognition of profit during the production process, although the result is evaluated after implementation. The sustainability of an enterprise's economy is assessed based on public reporting data, which is based on a capitalized estimate of expected revenues, but in some cases current market prices are also used to obtain these estimates. However, the presented conceptual position of economic sustainability is not a panacea and needs an open critical argument.

\section{References}

1. A.V. Poroshin, E.V. Porokhina, Yu.N. Soina-Kutishcheva, V.V. Barylnikov, Fundamental research, 12, 816 (2014) 
2. S.I. Ozhegov, Dictionary of the Russian language, 848 (1953)

3. M.P. Tumanov, Control theory. Theory of linear automatic control systems: a tutorial, $82(2005)$

4. L. D. Povzner, Control systems theory: Textbook for universities, 472 (2002)

5. V.N. Leksin, B.N. Porfiriev, Economy of the region, 13 (4), 985 (2017)

6. L.I. Abalkin, Scientific works of the free economic society of Russia, 195 (6), 79 (2015)

7. A.L. Bobrov, K.V. Papenkov, Bulletin of the Moscow University. Series 6: Economics, 1, 106 (2005)

8. D.V. Gordienko, National interests: priorities and security, 15 (72), 6, 33 (2010)

9. I.N. Petrenko, Economic security of Russia, monetary factor (2002)

10. L. T. Gilyarovskaya, Analysis and assessment of the financial stability of commercial organizations: a textbook for university students studying in the specialties 080109 "Accounting, analysis and audit", 080105 "Finance and credit", 159 (2015)

11. G.V. Savitskaya, Analysis of the economic activity of the enterprise: textbook, 378 (2013)

12. V.V. Kovalev, O.N. Volkova, Analysis of the economic activity of the enterprise: textbook, 424 (2007)

13. M.V. Melnik, Accounting. Analysis. Audit, 4, 16 (2015)

14. L.I. Kravchenko, Analysis of economic activities in trade: textbook. for students of econ. specialties of institutions providing higher education (2005)

15. A.D. Sheremet, Audit and financial analysis, 1, 154 (2017)

16. A.D. Sheremet, R.S. Saifulin, Methodology for a comprehensive analysis of the economic activity of an industrial enterprise (association): textbook, 232 (1980)

17. M.S. Abryutina, A.V. Grachev, Analysis of the financial and economic activities of the enterprise: study guide, 272 (2001)

18. V.V. Mokeev, E.V. Bunova, Financial analytics: problems and solutions, 31 (265), 2 (2015)

19. A.M. Platonov, S.Yu. Pleshkov, Economy of the region, 4 (16), 240 (2008)

20. V.I. Zakharchenko, Mechanical engineer, 1, 9 (2002)

21. A.S. Barkanov, Construction Economics, 8, 35 (2005)

22. I.V. Bryantseva, Economic sustainability of the enterprise: essence, assessment, management: textbook, 150 (2007)

23. V.V. Ioffe, Modern issues of enterprise management in the service sector: collection of articles, 59 (2004)

24. N.S. Necheukhina, O.V. Mustafina, L.N. Kuklina, Economy of the region, 14 (3), 836 (2018)

25. N.S. Necheukhina, O.V. Mustafina, Audit, 12, 33 (2017)

26. N.S. Necheukhina, O.V. Mustafina, L.N. Kuklina, Journal of Economic Theory, 17 (2), 346 (2020)

27. A. Bibigul, International Multidisciplinary scientific conference on social Sciences and arts SGEM2014, 2(2), 11 (2014)

28. S.G. Svetunkov, Economy of the region, 12 (3), 966 (2016)

29. I.M. Golova, A.F. Sukhovey, N.L. Nikulina, Economy of the region, 13 (1), 308 (2017)

30. M.R. Safiullin, L.A. Elshin, M.I. Prygunova, Economy of the region, 13 (2), 604 (2017) 
31. Y. Dolgikh, Y. Slepukhina, Materials of the 2nd International Scientific Conference on New Industrialization: Global, National, Regional Dimension (SICNI 2018), 240, 146 (2018)

32. E.Yu. Omelchenko, N.O. Omelchenko, Materials of the 2nd International Scientific Conference on New Industrialization: Global, National, Regional Dimension (SICNI 2018), 240, 218 (2018)

33. O.V. Mustafina, Bulletin of the South Ural State University, 127 (2020) 